\title{
Poéticas em arte sonora: entrevista com Paulo Nenflidio
}

\author{
Roseane Yampolschi, Clayton Rosa Mamedes, Paulo Nenflidio.
}

\author{
Universidade Federal do Paraná| Brasil
}

\begin{abstract}
Resumo: Paulo Nenflidio, em sua nota biográfica, se apresenta como um artista que trabalha na intersecção entre arte, ciência e tecnologia. Artista múltiplo e inventivo, suas obras compreendem esculturas, instalações, objetos, instrumentos e desenhos em que som, eletrônica, movimento, construção, invenção, aleatoriedade, física, controle, automação e gambiarra se unem como elementos de expressão artística. Paulo Nenflidio é formado em Artes Plásticas pela Escola de Comunicação e Artes da Universidade de São Paulo. É técnico em eletrônica pela Escola Técnica Estadual Lauro Gomes de São Bernardo do Campo. Natural de São Bernardo do Campo, o artista mantém nesta cidade seu ateliê. Nesta entrevista, buscamos aprofundar nosso estudo sobre questôes poéticas próprias ao trabalho de Paulo Nenflidio. Como se desenvolveu sua trajetória criativa, inspirações conceituais que guiaram o desenvolvimento de seus processos criativos e de suas pesquisas artísticas; assim como, também, o papel do som e do silêncio como formas de expressão poética. A presente entrevista foi realizada por e-mail, de forma escrita, entre os dias 20 e 24 de julho de 2021.
\end{abstract}

Palavras-chave: Paulo Nenflidio, arte sonora, processos criativos, poética.

\begin{abstract}
Paulo Nenflidio, in his biographic note, presents himself as an artist who works at the intersection between art, science and technology. A multiple and inventive artist, his works comprise sculptures, installations, objects, instruments and drawings in which sound, electronics, movement, construction, invention, randomness, physics, control, automatons, and workaround come together as elements of artistic expression. Paulo Nenflidio holds a degree in Fine Arts from the School of Communication and Arts of the University of São Paulo and is an electronics technician graduated from the Lauro Gomes Technical School in São Bernardo do Campo. Born in São Bernardo do Campo, the artist maintains his studio in this city. In this interview, we seek to deepen our study about the poetics of Paulo Nenflidio's works. How his creative trajectory developed, conceptual inspirations that guided the development of his creative processes and his artistic research, as well as the role of sound and silence as forms of poetic expression are issues addressed in this conversation. This interview was conducted by email, between the 20th and 24th of July 2021.
\end{abstract}

Keywords: Paulo Nenflidio, sound art, creative processes, poetics. 
Levando-se em consideração o seu olhar retrospectivo para a sua própria formação, quais seriam os principais aspectos que você considera relevantes para a sua trajetória criativa ao longo do tempo?

Creio que o primeiro aspecto relevante teria relação com minha própria natureza. Eu era uma criança que gostava de brincar de inventar coisas, de desmontar brinquedos e objetos da casa para entender o funcionamento (aliás até hoje tenho fascínio pelo funcionamento de relógios de corda devido à sua estrutura similar à de um sistema vivo, mas que, no entanto, é mecânico). Em casa havia ferramentas do meu pai (serrote, martelo, alicate etc.), as quais eu usava pra criar brinquedos de madeira. Acho que tenho uma herança genética: meu avô era marceneiro (pai da minha mãe) e meu pai costumava consertar os eletrodomésticos, inclusive a televisão de tubo antiga, sem nunca ter estudado eletrônica. Hoje, eu tenho equipamentos como o osciloscópio e o multímetro que facilitam descobrir qual é o defeito que esses objetos apresentam, facilitando o conserto. Sempre fico imaginando como meu pai conseguia consertar esses eletrônicos sem ter estudado e sem equipamentos. Acho que ele identificava visualmente os componentes queimados, e acho que tinha a intuição desenvolvida para conseguir identificar e consertar os problemas. Além do fator genético, acho que tem a questão de ter crescido numa cidade que tem um histórico de ser uma cidade operária (São Bernardo do Campo); antes da indústria de

\section{Regarding your retrospective view at your own formation, what would you consider the main relevant aspects that strengthen your creative trajectory over time?}

I believe that the first relevant aspect has to do with my own nature. I was a child who liked to play by inventing things, disassembling toys and objects in the house to understand how they work (in fact, until now I am fascinated by the operation of windup watches because they look like a living system, though they are mechanical). At home there were tools from my father (hacksaw, hammer, pliers, etc.) that I used to create wooden toys. I think it has a genetic heritage, my maternal grandfather was a carpenter and my father used to fix appliances, including the old tube television, without ever having studied electronics. Today I have equipment such as an oscilloscope and a multimeter that make it easy to find out what defect these objects have and then it becomes easy to fix. I always wonder how my father managed to fix these electronics without having studied and without equipment. I think he visually identified the burnt components, and I think he had the intuition developed to detect and fix the problems. Besides the genetic factor, I think there is the issue of having grown up in a city that has a working-class city's history (São Bernardo do Campo); before the car industry, my city was already famous in the furniture industry. Near my house there were many 
automóveis, minha cidade já era famosa pela indústria moveleira. Perto da minha casa havia muitas fábricas. Uma delas mantinha um portão aberto, e ali eu coletava pedaços de madeira que haviam sido descartados. Com esses pedaços eu construía e inventava meus primeiros objetos, que eram brinquedos ou coisas para usar em casa. Desde cedo, sempre gostei muito de manipular madeira.

Por outro lado, desenhar era também um tipo de diversão prazeroso. Também sempre tive um ouvido muito sensível. Comecei a me interessar por música e por instrumentos enquanto ainda era criança. Também me lembro do meu primeiro contato com a arte por meio de fotografias coloridas de obras da via sacra do mestre do barroco brasileiro "Aleijadinho" em uma enciclopédia ilustrada da editora Abril. Achei fantástico quando as vi, e soube, naquele instante, que, um dia, eu também seria escultor. Ainda teve uma questão relacionada à ciência eletrônica. Certo dia, meu pai construiu um motor de bobina de fio de cobre e imã. Um motor bem simples que os livros de física ensinavam a construir como experiência. Mais um tema com o qual fiquei maravilhado.

Havia muitos interesses para seguir: música, eletrônica, artes visuais... Mas também havia a preocupação de ter uma formação voltada ao trabalho. Então, quando fiz o colégio, optei pelo técnico em eletrônica, que mesclava a grade das disciplinas com o ensino de eletrônica. Depois, trabalhei três anos na indústria eletrônica, o que sedimentou o conhecimento que eu havia adquirido no colégio. Passado esse tempo, resolvi ingressar na factories. One of them kept an open gate where I collected pieces of wood that had been discarded. With these pieces I built and invented my first objects that were toys or things to use at home. From an early age, I have always enjoyed the handling of wood.

On the other hand, drawing was also a pleasurable kind of fun. I've always had a very sensitive ear. I started getting interested in music and instruments already as a child. I remember my first contact with art through color photographs of the via sacra works by the Brazilian baroque master Aleijadinho. It was from an illustrated encyclopedia by Abril publishing house. When I saw it, I thought it was fantastic and I knew at that moment that one day I would also be a sculptor. There was still a question related to electronic science. One day my father built a magnet and copper wire coil motor. A very simple engine found in physics textbooks to build as an experiment. Another theme that I was delighted.

There were many interests to pursue: music, electronics, visual arts. But there was also a concern with having a qualification geared to working life. So, when I went to high school, I followed the technical course in electronics, which mixed the regular program of disciplines with those related to electronics. Then I worked for three years in the electronics industry and this cemented the knowledge I had acquired in high school. After this time, I decided to follow an undergraduate course in visual arts. My main interest was to learn all the 
faculdade para estudar artes visuais. Meu interesse maior era aprender todos os meios, a fotografia, a cerâmica, gravura, pintura, desenho etc. Fiz o curso de artes visuais na Escola de Comunicaçốes e Artes da Universidade de São Paulo. Ainda na Universidade, tive a oportunidade de cursar disciplinas extracurriculares na área da música. Fiz História da Eletroacústica e Fundamentos da Acústica Aplicados à Música. Toda essa formação foi muito importante para mim e, ainda na faculdade, comecei a criar minhas primeiras obras que uniam música com artes visuais, algumas delas usando meios eletrônicos no processo.

Um momento importante foi a Bolsa de Residência do Museu da Pampulha em 2003, onde pude ficar durante um ano em Belo Horizonte, com acompanhamento crítico, desenvolvendo a obra Música dos Ventos.

Em 2004, eu concluí a faculdade; aliás, apresentei a obra Música dos Ventos como trabalho de conclusão e então montei meu ateliê na antiga casa onde cresci, que, na época, estava desocupada. Ainda em 2004, uma galeria no Rio de Janeiro, A Gentil Carioca, se interessou em comercializar minhas obras; e então comecei a ser representado por esta galeria.

O período de 2003 a 2015 foi de crescimento econômico no Brasil, e as artes se beneficiaram deste movimento. Havia uma forte demanda de colecionadores por obras; então, este foi um período bom para a carreira de muitos artistas. Com essa demanda e participando em feiras, exposições, residências etc., eu intensifiquei a produção e foquei media, photography, ceramics, printmaking, painting, drawing, etc. I took the course in visual arts at the School of Communications and Arts of the University of São Paulo. Still at the University, I had the opportunity to take extracurricular courses in the field of music. I did History of Electroacoustic and Acoustic Fundamentals Applied to Music. All this training was very important to me and while still in university I started to create my first works that combined music with visual arts, some using electronic resources in their creative process.

An important moment was the Pampulha Museum Residency Scholarship from 2003, where I was able to stay for a year in Belo Horizonte, with critical monitoring, developing the work Música dos Ventos.

In 2004 I finished my university course; in fact, I presented Música dos Ventos as the final work and then I set up my studio in the old house where I grew up, which at the time was unoccupied. Still in 2004, the Gentil Carioca gallery, in Rio de Janeiro, became interested in selling my works; and since then, I started to be represented by this gallery. The period from 2003 to 2015 was one of economic growth in Brazil, and the arts benefited from this movement. There was a strong demand from collectors for works; thus, it was a good period for many artists' careers. With this present demand and also the participation in fairs, exhibitions, residencies, etc. I ended up intensifying production and focusing my time entirely on researching and 
meu tempo integralmente na pesquisa e criação das minhas obras. Houve um ano de pico em que eu produzi uma obra por mês. Estava interessado em criar obras relacionadas à física do som e ao movimento. creating my works. There was a peak year where I produced one piece per month. I was interested in creating works related to the physics of sound and movement.

FIGURA 1- Música dos Ventos: vista interna (esquerda) e externa (direita). Música dos Ventos: inner (left) and external view (right) ${ }^{1}$.
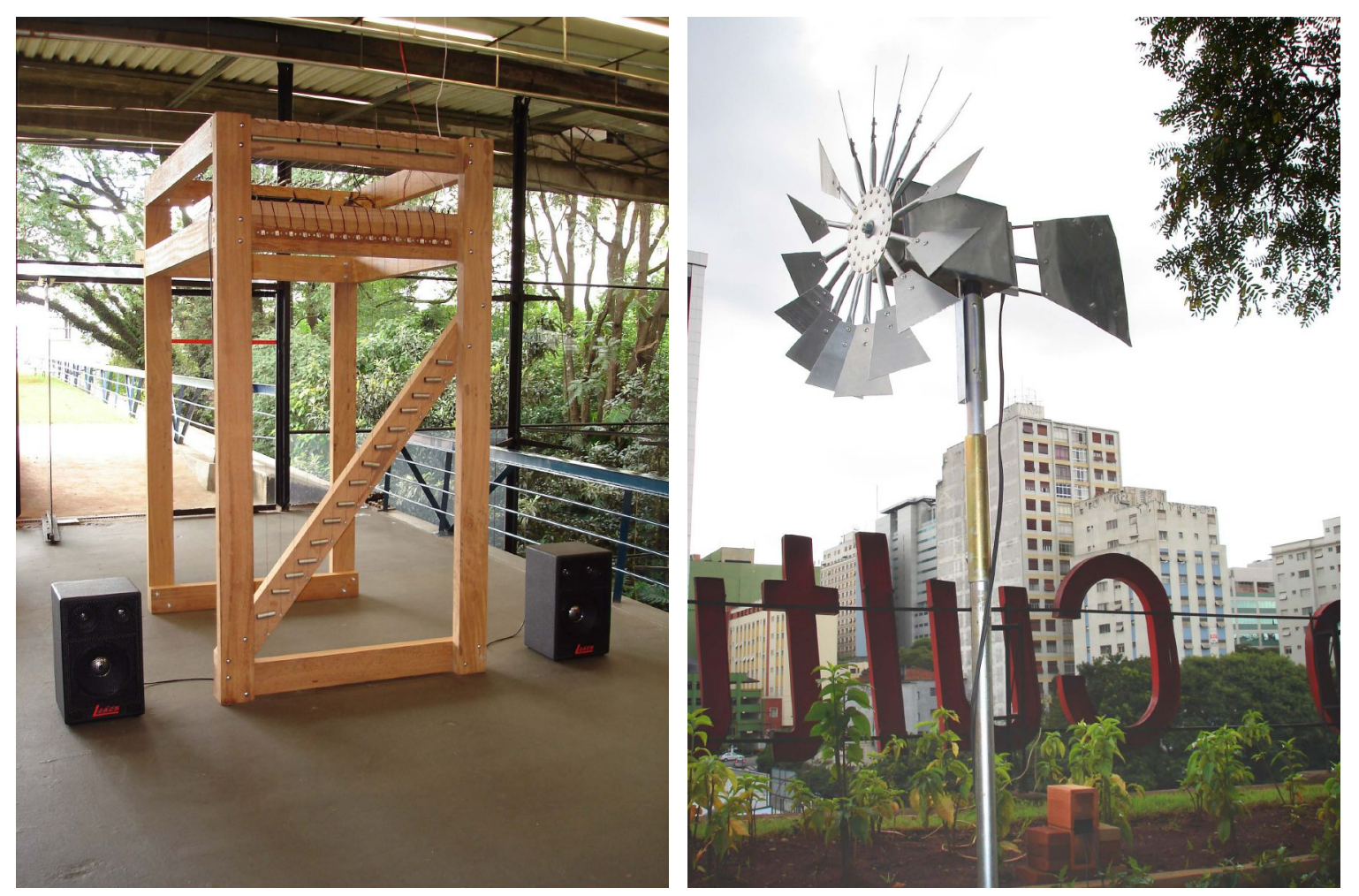

Fonte: Portfolio do artista.

Source: Artist's portfolio.

\section{Nesta trajetória, o que o levou a se interessar pelo som enquanto um elemento de destaque em várias de suas obras?}

Isto tem relação com meu interesse por música e por instrumentos. Mas, mais fundo que isso, tenho interesse pela própria natureza do som. Meus
In this trajectory, what led you to become interested in sound as a prominent element in several of your works?

This relates to my interest in music and instruments. But, deeper than that, I'm interested in the very nature of sound. My works are

\footnotetext{
${ }^{1}$ Disponível em / available at: https://youtu.be/mQplkUFE2fs. Acesso: 22 ago. 2021 / Accessed: Aug. $22,2021$.
} 
trabalhos, algumas vezes, são mais relacionados à teoria da música (por exemplo: Música dos Ventos, Gerador de Música, Monjolofone, Lusco-Fusco); outros, ao ruído como música (por exemplo: Gotejador, White Noise, Lugares Sonoros, Decabráquido Radiofônico) e também ao som na física (por exemplo: Teclado Sísmico, Monocórdio Infinito, Bicórdio Infinito). Também me interessa a história da música mecânica, os autômatos, caixas de música... Por isso, algumas obras acabam se relacionando também com este tema (por exemplo: Módulo Lunar, Máquina do Trovão, Virus). Mais recentemente, tenho extrapolado esses conceitos e criado obras que estão mais relacionadas com o silêncio ou com a ciência em geral. sometimes more related to music theory (for instance: Música dos Ventos, Gerador de Música, Monjolofone, Lusco-Fusco); others to noise as music (for instance: Gotejador, White Noise, Lugares Sonoros, Decabráquido Radiofônico) as well as to sound in physics (for instance: Teclado Sismico, Monocórdio Infinito, Bicórdio Infinito). I'm also interested in the history of mechanical music, automatons, music boxes. That's why some works also end up relating to this theme (for instance: Módulo Lunar, Máquina do Trovão, Virus). More recently I have extrapolated these concepts and created works that are more related to silence or science in general.

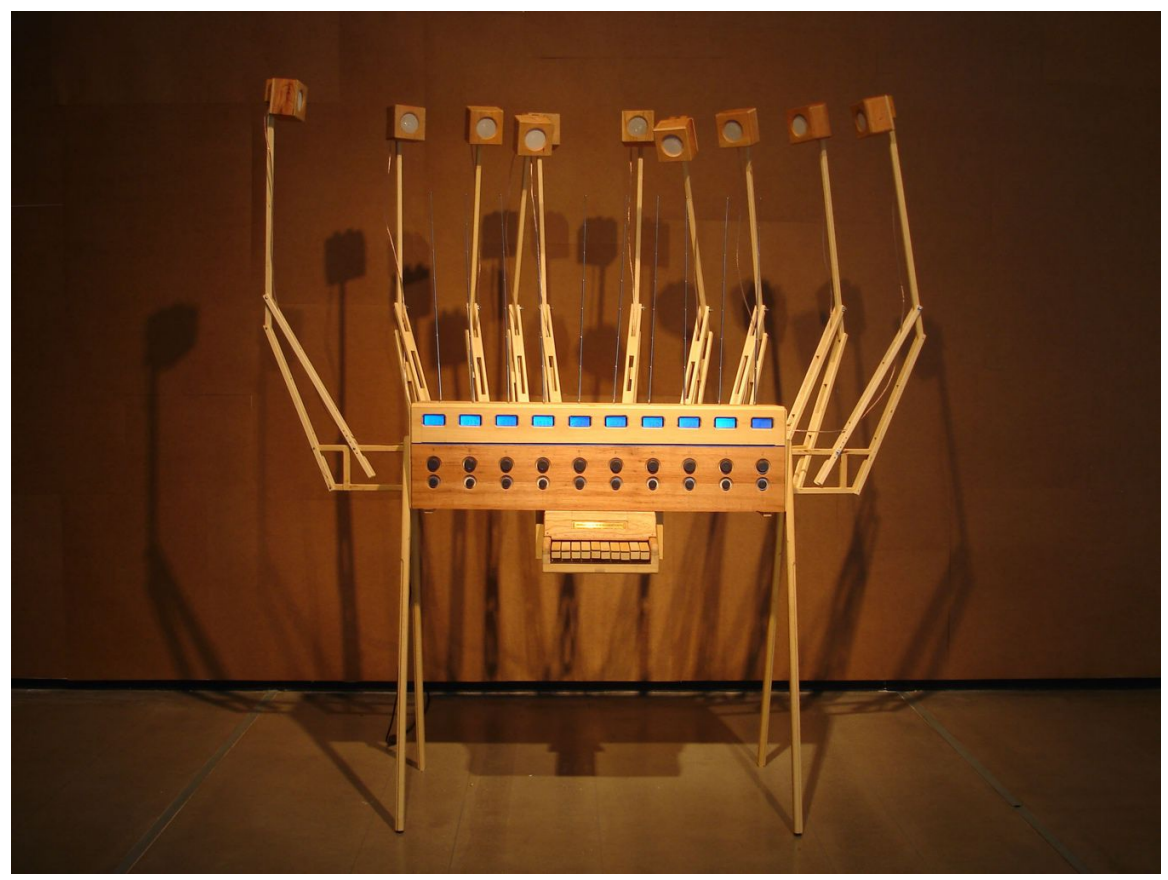

Fonte: Portfolio do artista

Source: Artist's portfolio

\footnotetext{
${ }^{2}$ Disponível em / available at: https://youtu.be/wZrx-1qqVMU. Acesso: 22 ago. 2021 / Accessed: Aug. 22, 2021.
} 


\section{FIGURA 3 - Monjolofone3.}

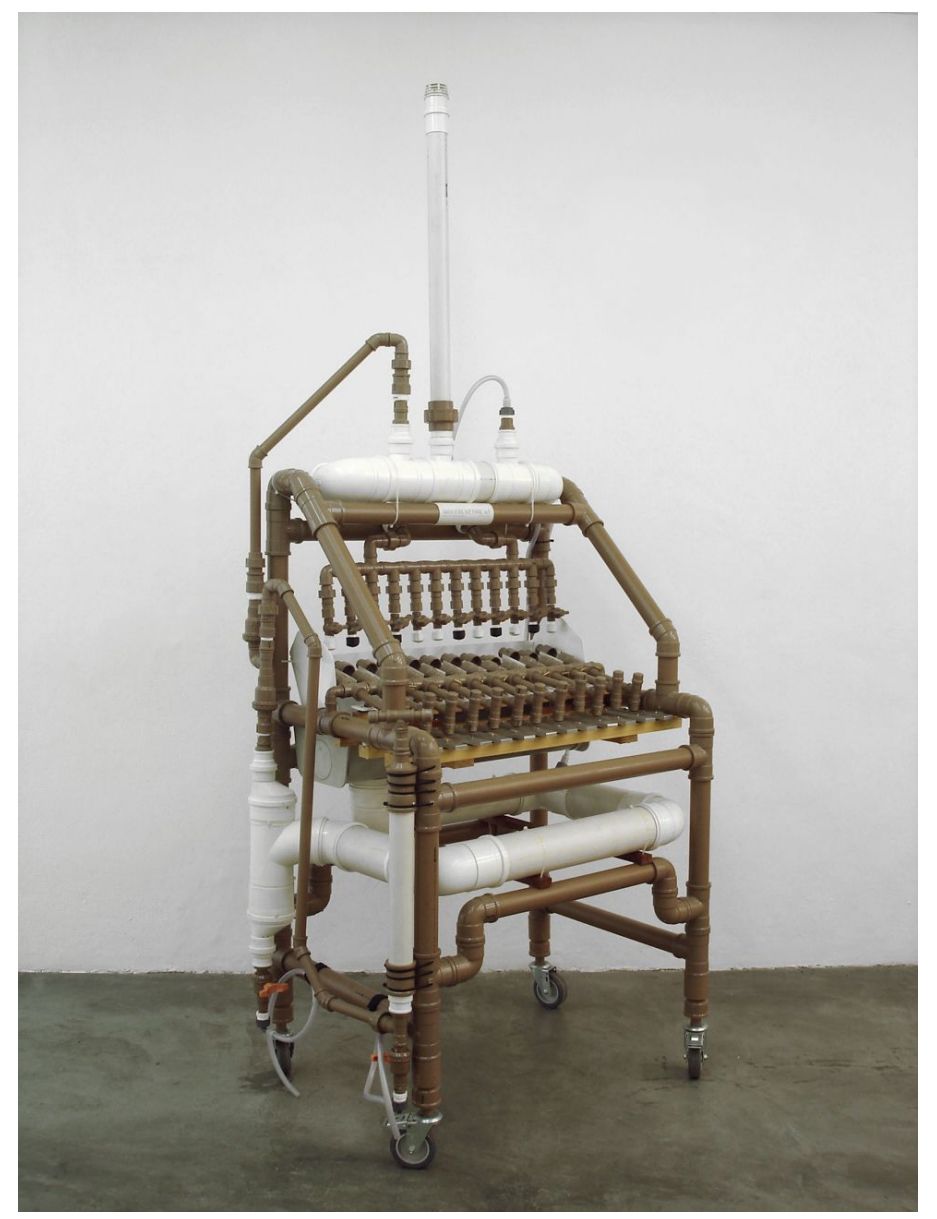

Fonte: Portfolio do artista. Source: Artist's portfolio.

A sua experiência criativa abarca um universo híbrido de invenções e descobertas. E, nesse universo, observamos uma alternância de elementos característicos que se destacam em cada obra, como resultado de um direcionamento poético e de escolhas sensíveis para construção dessas obras. À luz dessa perspectiva, você poderia destacar artistas que foram ou têm sido relevantes para o seu trabalho neste contexto?

\begin{abstract}
Your creative experience encompasses a hybrid universe of inventions and discoveries. Among this universe, we observe an alternation of characteristic elements that stand out in each work, as a consequence of both a poetic orientation and sensitive choices taken during the construction of these works. Considering this perspective, could you highlight artists who were or have been relevant to your work in this context?
\end{abstract}

\footnotetext{
${ }^{3}$ Disponível em / available at: https://youtu.be/jMUHyK_e2mw. Acesso: 22 ago. 2021 / Accessed: Aug. 22, 2021.
} 
No geral, tenho interesse pelos artistas inventores, classificação na qual me incluo, alinhado com Jean Tinguely, Palatinik, Guto Lacaz e Walter Smetak. No cinema, gosto muito dos filmes de Stanley Kubric (o filme 2001, Uma Odisséia no Espaço foi, para mim, fonte de inspiração na criação de várias obras). Na música, Alvin Lucier, Steve Reich e algumas obras de John Cage. Além disso, muitas fontes de inspiração vêm diretamente de assuntos relacionados à natureza.
In general, I'm interested in inventor artists, a classification which I include myself, along with Jean Tinguely, Palatinik, Guto Lacaz, Walter Smetak. In the cinema, I really like Stanley Kubric's films (2001, A Space Odyssey was a source of inspiration for me in the creation of several works). In music, Alvin Lucier, Steve Reich, and some works by John Cage. Also, many sources of inspiration come directly from nature-related subjects.

FIGURA 4 - Máquina do Trovão ${ }^{4}$.

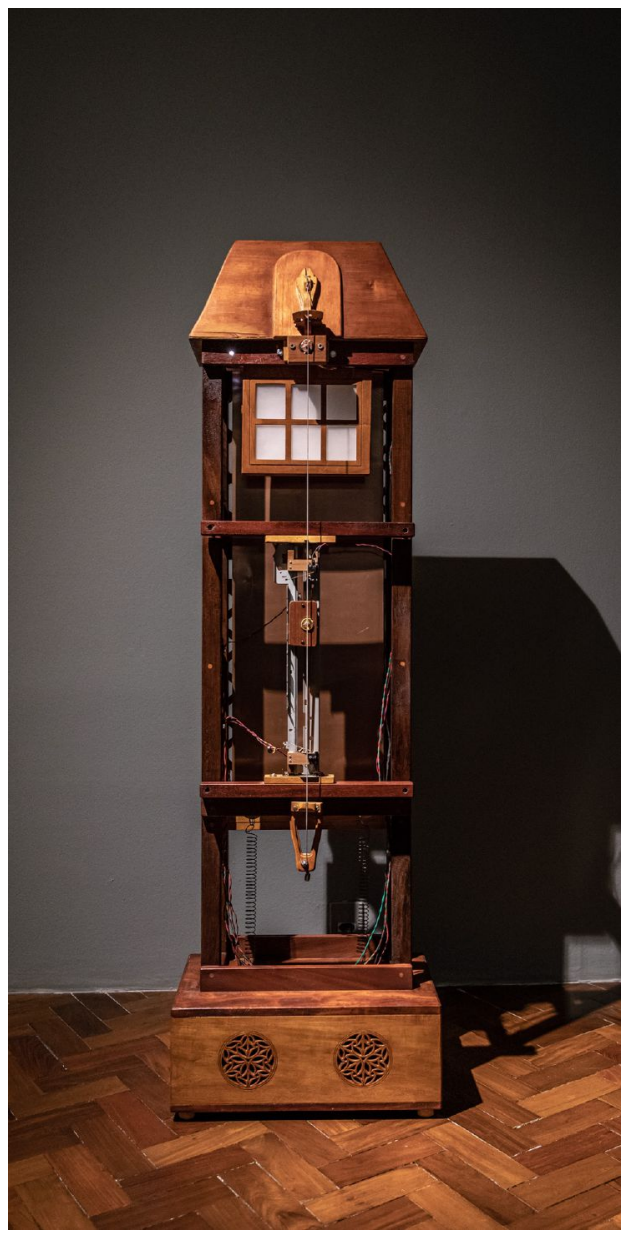

Fonte: Portfolio do artista.

Source: Artist's portfolio.

\footnotetext{
${ }^{4}$ Disponível em / available at: https://youtu.be/tWJgVcVSvkk. Acesso: 22 ago. 2021 / Accessed: Aug. 22, 2021.
} 
A sua obra, como um todo, apresenta uma acentuada inspiração poética que direciona conceitualmente os seus trabalhos. Duas delas aparecem com frequência: a poética do invisível e a poética do acaso ou do indeterminado. Quais obras você considera como mais relevantes nesse sentido? Há outras poéticas que foram ou têm sido importantes para o desenvolvimento do seu trabalho como artista atualmente e que você gostaria de destacar?

O invisível me interessa pelo fator mágico; tudo o que sabemos que existe, mas não é percebido pelos olhos. Meus trabalhos estão repletos deste universo invisível, o eletromagnetismo, o som, as ondas de rádio, a eletricidade. $\mathrm{O}$ acaso, para mim, intensifica o aspecto mágico, pois é como se a obra ganhasse vida própria. Crio elementos de construção nas obras; quando a obra começa a funcionar, o que está acontecendo naquele momento é único, pois é ao acaso.

Como exemplo, primeiro, temos a Música dos Ventos. Criei um aparato com cata-ventos e um instrumento de cordas cuja composição sonora é determinada pelo vento. Esta obra une a força invisível dos ventos ao acaso da composição que é criada em tempo real e nunca se repete. E apesar de nunca se repetir, percebese na melodia um padrão definido pelo vento. O que ouvimos como composição é semelhante ao movimento da copa das árvores quando agitadas pelo vento.

Também temos o Decabráquido Radiofônico. Neste, um teclado parecido com o de um piano chaveia a
Your artworks, as a whole, have a marked poetic inspiration that directs conceptually your creative process. Two of them appear frequently: the poetics of the invisible and the poetics of chance or indeterminacy. Which works do you consider the most relevant in this sense? Are there other poetics that were or have been important for the development of your actual creative process that you would like to highlight?

The invisible interests me by the magical factor, everything we know that exists, but it's not perceived by the eyes. My works are full of this invisible universe, electromagnetism, sound, radio waves, electricity. Chance operations for me intensifies that magical aspect because it is as if the work takes on a life of its own. I create construction elements in the works; when they start to function, what is happening at that moment is unique, as it is random. As a first example, we have Música dos Ventos. I created an apparatus with weathervanes and a string instrument whose sound composition is determined by the wind. This work unites the invisible force of the winds with the randomness of the composition that is created in real time and never repeated. Although it is never repeated, a pattern defined by the wind can be perceived in the melody. What we hear as composition is similar to the movement of treetops when shaken by the wind.

We also have the Decabráquido Radiofônico. Here, a piano-like keyboard switches the sound output of 10 
saída de som de dez rádios. Os rádios podem ser sintonizados em estações diversas e o volume de cada um deles também pode ser ajustado. Quando se toca este teclado, se houve pedaços picotados do som que está sendo transmitido naquele instante. É um instrumento de teclas, onde o som produzido depende das rádios locais. Desta forma, o objeto conecta-se ao lugar por meio das ondas de rádio. Ele torna audível o caos invisível das ondas radiofônicas.

O Monjolofone é outra obra que une esses dois fatores.

A energia invisível do movimento da bomba hidráulica da obra transfere a água do coletor, na parte inferior da obra, para um reservatório na parte superior. Aí, a água é armazenada como energia potencial. Quando os registros são abertos, a água enche os monjolos que se movimentam e tocam o vibrafone, produzindo música. Nesta obra, pode-se determinar uma escala musical ao abrir e fechar os registros. Também pode-se controlar a velocidade da música criada, deixando os registros mais ou menos abertos. Mas qual será a sequência de notas é um fator de acaso. Cada vez que o Monjolofone toca, uma música nova é criada.

Além dessas obras, tenho construído outras esculturas nas quais faço uso de microcontroladores; e, ao programá-los, eu crio variáveis com a função randômica. Por exemplo, Speaker produz frases musicais como um cantor de jazz, com notas cuja frequência, duração e número de sílabas por frase são aleatórias. Na Máquina do Trovão há diversas funções (vento suave, médio e forte, trovoada, vibração eletromagnética de uma corda, silêncio) que ficam radios. Radios can be tuned to different stations and the volume of each one of them can also be adjusted. When playing this keyboard, we can listen to chopped sound bits being transmitted at that moment. It is a keyboard instrument where the sound produced depends on local radios. In this way, the object is connected to the place through radio waves. It makes audible the invisible chaos of radio waves.

The Monjolofone is another work that unites these two factors. The invisible energy of the hydraulic pump movement transfers the water from the collector, at the bottom part of the work, to a reservoir at the top of it. There the water is stored as potential energy. When the valves are opened, the water fills the moving monjolos that play the vibraphone, producing music. In this work, a musical scale can be determined by opening and closing the registers. You can also control the speed of the music created by letting the registers more or less open. But what will the sequence of notes be is also random. Each time Monjolofone plays, a new song is created.

In addition to these works, I have built other sculptures in which I use microcontrollers; and while programming them I create variables with a random function. For example, Speaker produces musical phrases like a jazz singer, with notes whose frequency, duration and number of syllables per phrase are random. In Máquina do Trovão there are several functions (soft, medium and strong wind, thunder, electromagnetic vibration of a string, 
rodando em loop numa programação que também possui variáveis randômicas.

É como se as obras tivessem vontade própria. silence) that keep running in a loop of a program, which also has random variables.

It's like the works would have a mind of their own.

FIGURA 5 - Speaker 5
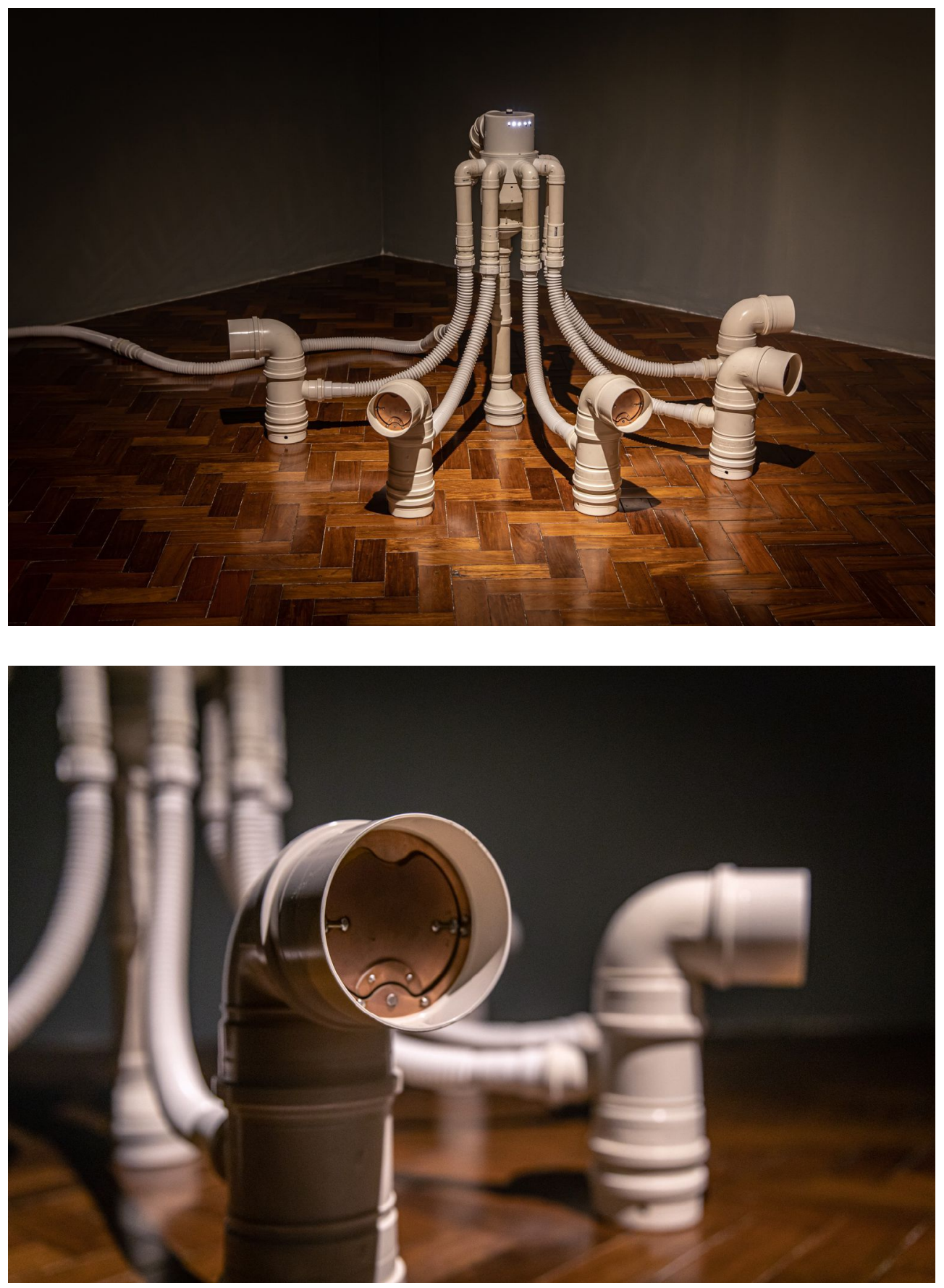

Fonte: Portfolio do artista.

Source: Artist's portfolio.

${ }^{5}$ Disponível em / available at: https://youtu.be/BCBW9Ufomro. Acesso: 22 ago. 2021 / Accessed: Aug. 22, 2021. 
Ainda em relação ao contexto da pergunta anterior, como você compreende as suas experiências com o som, especificamente como princípio para a construção de suas obras recentes, como 4,33 x, a Baleia e Intersecção n. 2 ?

$\mathrm{Na}$ obra $4,33 x$, eu usei a potência do som silenciado. Esta obra, apesar de sonora, não emite som. Na verdade, um ouvido mais atento percebe o som do ruído do movimento do pêndulo de madeira. Mas essa não é a intenção da obra. Nessa obra, a ideia é perceber o som na sua forma visual. O pêndulo toca a taça com água no limite do seu movimento e de forma tão sutil que não produz som. Porém, a taça vibra e nota-se o som pela vibração visual da superfície da água. Quando tive a ideia de criar essa obra, por ser minha obra que trata do silêncio, pensei em criar o pêndulo com o comprimento de 4,33 metros, uma referência à composição silenciosa 4'33, do John Cage. Na obra do Cage, essa é uma medida de tempo. Na minha, uma medida espacial. De fato, originalmente construí um pêndulo com 4,33 metros de comprimento. Essa obra original eu doei para o Museu da UNTREF, na Argentina. Depois, criei a versão 4,33 x, que é retrátil, para se adaptar às diversas alturas dos locais expositivos, podendo variar de 3,7 a 2,5 metros de altura. Mantive o nome 4,33 como referência à composição de John Cage e adicionei a letra " $\mathrm{x}$ " como uma unidade variável de medida. Ou seja, a obra mede 4,33 x metros de
Still regarding the context of the previous question, how do you understand your experiences with sound, specifically, as a principle for the construction of your recent works, such as $4.33 x$, Baleia and Intersecção n. 2?

In the work 4.33x, I used the power of the muted sound. This work, although conceived as a sounding one, does not emit a sound. In fact, a more attentive ear perceives the noise sound of the movement of the wooden pendulum. But this is not the intention of the work. In this work, the idea is to perceive sound in its visual form. The pendulum touches the crystal goblet with water at the limit of its movement and in a way so subtly that it produces no sound. However, the goblet vibrates and the sound is noticed by the visual vibration of the water surface. When I had the idea to create this work, as it is a work that deals with silence, I thought of creating a pendulum with a length of 4,33 meters. A reference to John Cage's silent composition entitled 4'33. In Cage's work it is a measure of time. In mine, a spatial measure. In fact, I originally built a pendulum length of 4,33 meters. This original work I donated to the UNTREF Museum in Argentina. Then I created the $4,33 x$ version, which is retractable to adapt to the different heights of the exhibition spaces, ranging from 3.7 to 2.5 meters in height. I kept the name 4,33 as a reference to John Cage's composition and added the letter " $\mathrm{x}$ " as a variable 
altura.

Baleia é uma obra de 2011, na qual eu estava investigando as questões cinéticas mescladas às questôes sonoras. Minha ideia nesta obra foi construir uma escultura inteiramente em latão e solda de estanho que, inspirada na forma de uma jubarte, ficasse flutuando no espaço. Dessa forma, seria como ver uma baleia dentro da água. Outra função dessa flutuação é que, com leves correntes de ar, a escultura se movimenta, e o ranger dos metais cria um som parecido com os produzidos por esses mamíferos dentro da água. Então, a ideia nessa obra seria produzir som com o acaso das correntes de ar. A escultura ficou muito bonita, como um desenho no espaço, mas o som não ficou tão legal. Montei dentro de uma feira na Art Basel. Num espaço aberto, talvez ela funcionasse melhor. Em Intersecção n.2, uma obra bem recente, fui além dos limites do que eu estava acostumado a criar. A ideia foi exatamente essa: sair da zona de conforto e experimentar outras formas de criação, nesse caso, o desenho geométrico tridimensional formando planos imaginários no espaço. Nessa obra, consegui efetivar algo que eu vinha buscando há muito tempo: criar uma obra extremamente simples com um mínimo de elementos construtivos (nesse caso, apenas pregos e fios elásticos). Os planos criados pelas linhas se contorcem e se interseccionam no espaço. No entanto, essa intersecção é apenas criada na visão, na imaginação. De fato, nenhuma das linhas se tocam. De certa forma, inspirado pelos desenhos que as ondas sonoras criam numa corda unit of measure. In other words, the work measures $4,33 x$ meters in height.

Baleia is a work from 2011, where I was investigating kinetic issues mixed with sound issues. My idea in this work was to build a sculpture entirely in brass and tin solder which, inspired by the shape of a humpback whale, would float in space. In this way, it would be like seeing a whale in the water. Another function of this fluctuation is that since the sculpture moves with light air currents, the creaking of metals creates a sound similar to those produced by these mammals in water. So, the idea in this work would be to produce sound with the random movements of the air currents. The sculpture looked beautiful, as a drawing in space, but the sound was not so nice. I set up in the Art Basel fair. Maybe it would work better in an open space.

In Intersecção n.2, a very recent work, I went beyond the limits of what I was used to create. The idea was exactly that, to leave the comfort zone and experiment with other forms of creation. In this case the three-dimensional geometric design forming imaginary planes in space. In this work I managed to accomplish something I had been looking for a long time: to create an extremely simple work with minimal constructive elements (in this case only nails and elastic threads). The planes created by the lines twist and intersect each other in space. However, this intersection is only created in vision, in imagination. In fact, none of the lines touch themselves. In a way, inspired by the 
em vibração, essa obra também pode ser considerada cinética, apesar de estática. O público é levado a percorrer a obra para conseguir ver os desenhos formados enquanto se anda em torno da obra. É o cinético do movimento do público do ponto de vista da obra.

Essas obras que extrapolam a questão sonora são, para mim, como uma abertura, uma liberdade de criação que o artista deve ter a fim de não ficar tão preso a um tema específico, sempre buscando caminhos novos de pesquisa e criação. drawings that the sound waves create in a vibrating string, this work can also be considered kinetic, albeit static. The public is taken to wander the work in order to see the drawings formed while walking around it. It is the kinetics of the visitors' movement, from the point of view of the work. These works, which go beyond the question of sound, are for me like an opening, a freedom of creation that the artist must have in order not to be so tied to a specific theme. Always new paths of research and creation.

FIGURA $6-4,33 x^{6}$.

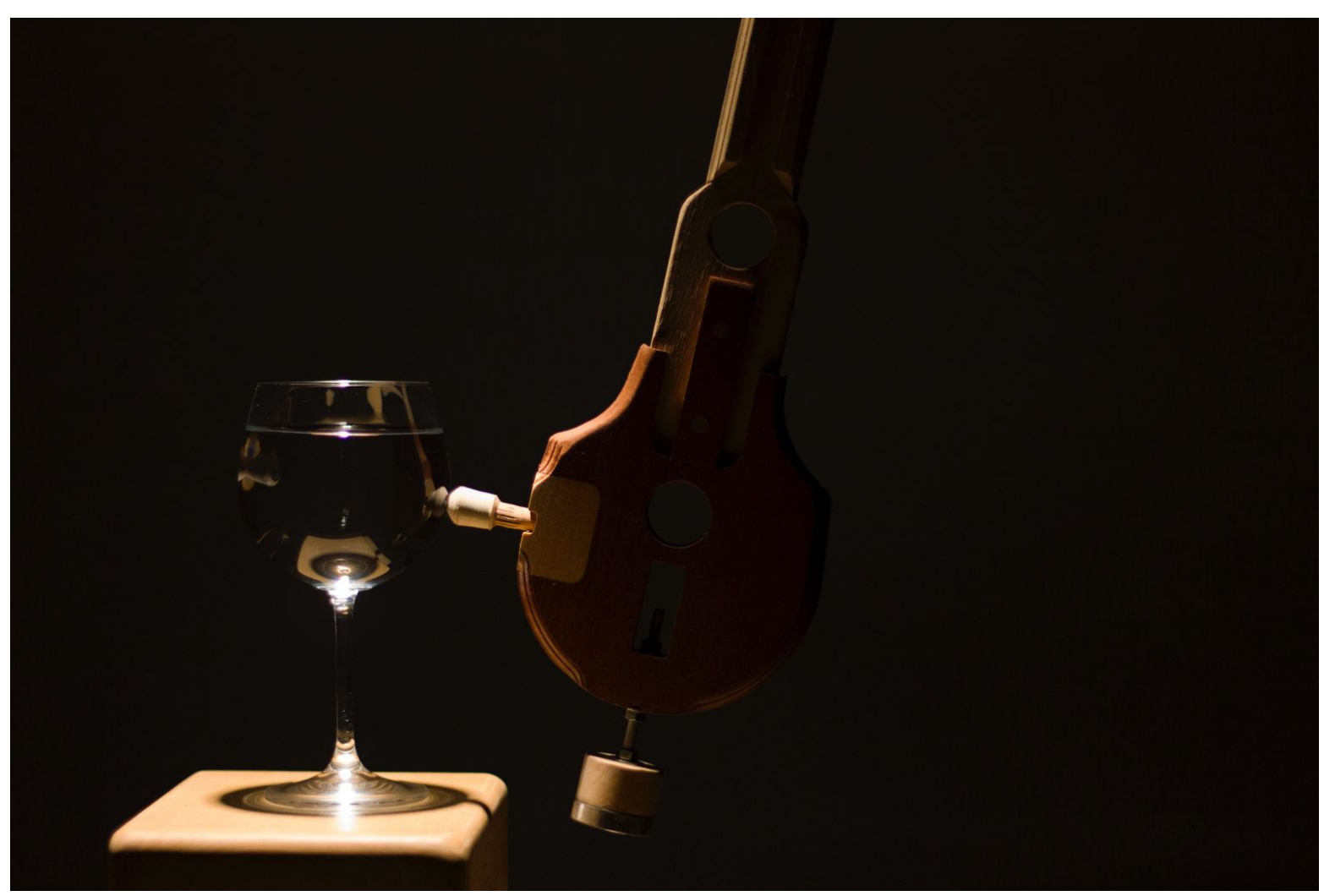

Fonte: Portfolio do artista.

Source: Artist's portfolio

\footnotetext{
${ }^{6}$ Disponível em / available at: https://youtu.be/FObw-hzmyHs. Acesso: 22 ago. 2021 / Accessed: Aug. $22,2021$.
} 
Em boa parte de seus trabalhos, os materiais usados apresentam aparências e/ou funçóes diversas ou conflitantes entre si, seja pelas suas características físicas sensíveis, seja pelas suas referências culturais e históricas, como em Totem, Speaker, 4,33 x e Máquina do Trovão. Como você percebe o impacto dessa relação entre os materiais constitutivos de suas obras - incluindo o som - em seus visitantes?

Pelo que já pude perceber, normalmente as pessoas ficam felizes ao visitar minhas exposições. Creio que isso se deva mais ao caráter lúdico das obras. Ou talvez por desviar alguns materiais de suas funçôes originais. Ou até mesmo, como falei de início, tudo o que eu crio, até hoje, envolve pesquisa e aprendizado, como numa brincadeira. Eu crio minhas obras brincando de aprender. É sempre um prazer. Acho que transmito esse prazer da criação nas obras, e o público sente isso. Em Totem, eu fiz uso da madeira como um material contrastante em relação a todos os tipos de materiais eletrônicos que fazem parte da obra. Totem é como se fosse um museu em si, com artefatos eletrônicos de algumas décadas. Nele há um aparelho reprodutor de $\mathrm{CD}$ de música com uma compilação de sons da história da música eletroacústica, aparelhos de fita K7, motores, um motor de enceradeira Arno antiga (era da minha mãe), rádio etc.

Em Speaker, subverto o uso de encanamentos de esgoto para construir a estrutura de uma escultura que possui circuitos eletrônicos e alto-falantes embutidos
In most of your works, the materials used have different or conflicting appearances and/or functions, either because of their physical characteristics, sensitive characteristics, or because of their cultural and historical references, for example in Totem, Speaker, $4.33 x$ and Máquina do Trovão. How do you see the impact of this relationship between the constituent materials of your works including sound - on your visitors

As far as I can tell, people are usually happy to visit my exhibitions. I believe this is due more to the playful feature of the works. Or perhaps because it deviates some materials from their original functions. Or even, as I said at the beginning, everything I create to this day involves research and learning, as if in a play. I create my works playing with learning, it's always a pleasure. I think I convey this pleasure of creation in the works and the public feels it.

In Totem, I made use of wood, as a contrasting material in relation to all kinds of electronic materials that are part of the work. Totem is like a museum in itself, with electronic artifacts from a few decades ago. It contains a CD player with a compilation of sounds from the history of electroacoustic music, Cassette tape devices, motors, an old Arno floor polisher motor (it was my mother's), radio, etc.

In Speaker, I subvert the use of sewage pipes to build the structure of a sculpture that has electronic 
na obra. Aliás, Speaker é o nome da obra porque ela possui cinco alto-falantes; mas a obra também é um "speaker" por ser um orador-cantor de jazz. circuits and speakers built into the work. By the way, Speaker is the name of the work as it has 5 speakers, but the work is also a speaker, it is a jazz singer speaker.

FIGURA 7 - Totem 7.

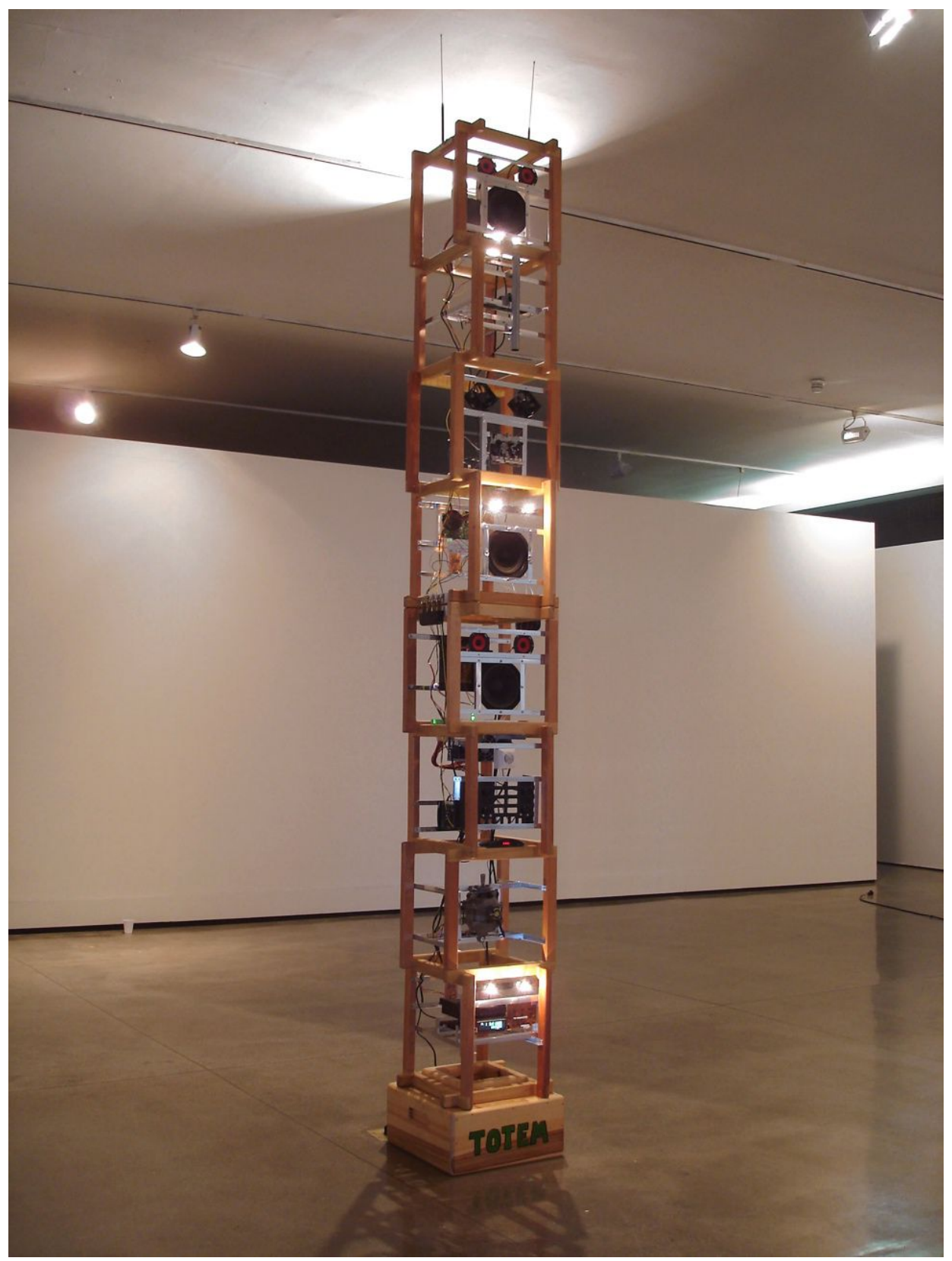

Fonte: Portfolio do artista.

Source: Artist's portfolio.

\footnotetext{
${ }^{7}$ Disponível em / available at: https://youtu.be/C_ _ h_N37dEU. Acesso: 22 ago. 2021 / Accessed: Aug. 22, 2021.
} 


\section{FIGURA 8 - Livro das águas ${ }^{8}$.}

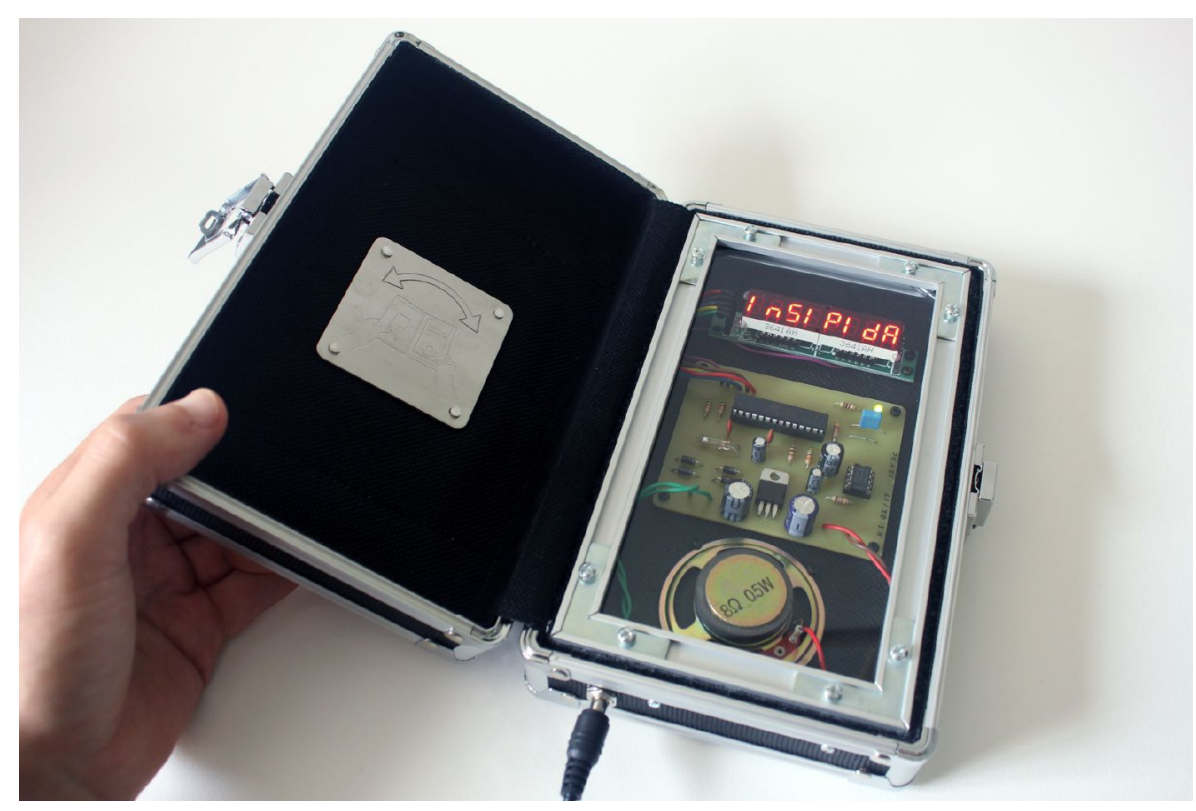

Fonte: Portfolio do artista.

Source: Artist's portfolio.

Em algumas de suas obras, a figuração geral das suas esculturas, podendo ser representativas ou não, geram aspectos culturais e simbólicos que ultrapassam ou estão em conflito com essas mesmas figurações. Isso acontece, por exemplo, em obras como a Baleia, Noise, Livro das Águas. Em paralelo, os materiais e elementos da natureza que compõem suas esculturas, como a água, o vento, a luz, a madeira, metais, pedras, objetos achados e sons diversos são usados para a sua invenção e novas descobertas. Você considera que a poesia que brota de suas obras, tendo em vista a integração desses aspectos materiais, culturais e simbólicos, contribui para a percepção de aspectos éticos e políticos em sua arte?
Figurative characteristics in some of your sculptures, which may or may not be representative, generate cultural and symbolic aspects that go beyond or are in conflict with these same figurative characteristics. For example, in works such as Baleia, Noise, Livro das Aguas. In parallel, the materials and elements from nature that compose your sculptures, such as water, wind, light, wood, metals, stones, found objects and variegated sounds are used for your invention and new discoveries. Considering the integration of these materials, cultural and symbolic aspects, do you consider that the poetics that emerge from your works contribute to the perception of ethical and political aspects in your art?

\footnotetext{
${ }^{8}$ Disponível em / available at: https://youtu.be/qe6HeHiWryA. Acesso: 22 ago. 2021 / Accessed: Aug. 22, 2021.
} 
De fato, na época em que eu estava escolhendo qual caminho seguir, uma possibilidade era faculdade de Ecologia. Sempre fui fascinado por assuntos relacionados aos seres vivos e ecossistemas. Muitas de minhas obras são inspiradas em formas de vida diversas e nas suas inteligências, como o movimento complexo das aranhas e suas teias. Existem questôes que fazem parte das obras que têm relação direta com as preocupações e impactos que nossas açóes geram no planeta. Mas tenho o cuidado de não ser explícito. Gosto dessas camadas de assuntos presentes nas obras sem ser literal, como no caso do Teclado Sísmico. Nesta obra, o assunto principal é a pesquisa e criação de um instrumento que poderia, de fato, estar num palco para uma apresentação sonora, mas cujo resultado sonoro é, ao mesmo tempo, o ruído do som dos motores dos marteletes e as ondas mecânicas da trepidação do chão gerado pelas marteladas das máquinas. Ainda tem a questão da variação de tons graves, pois é possível controlar a velocidade da frequência das marteladas criando uma música de ruídos. Lá no fundo, esse instrumento-máquina, semelhante a um caranguejo, é inspirado nas rápidas transformações urbanas, nas máquinas quebrando ruas, construindo viadutos, destruindo velhas residências e construindo condomínios de prédios; e ruas ocupadas mais por máquinas do que por pessoas. Outra obra, o Experimento de Quase Curto, foi construída num momento em que o país estava sendo intencionalmente dividido e polarizado entre esquerda e direita (uma estratégia já conhecida e reproduzida em outros momentos da história a fim de
In fact, at the time I was choosing which way to go, one possibility was to follow an undergraduate course on Ecology. I have always been fascinated by subjects related to living beings and ecosystems. Many of my works are inspired by different ways of life and their intelligence. For example, the complex movement of spiders and their webs. There are issues that are part of the works that are directly related to the concerns and impacts that our actions generate on the planet. But I'm careful not to be explicit. I like these layers of subjects present in the works without being literal. For example, Teclado Sismico. In this work, the main subject is the research and creation of an instrument that could actually be on a stage for a sound presentation, but the sound result is at the same time the noise of the jackhammer engines and the mechanical waves of the ground vibration generated by hammering machines. There is still the question of the variation of the bass tones, as it is possible to control the frequency-speed of the hammering, creating a music out of noises. Deep down, this crab-like machine instrument is inspired by rapid urban transformations, by machines breaking streets, building viaducts, destroying old homes and building condominiums of buidings; and the streets occupied more by machines than people.

Another work, Experimento de Quase Curto was built at a time when the country was being intentionally divided and polarized between left and right wings (a strategy already known and reproduced at other times in history in order to 
enfraquecer a unidade), e que um possível encontro dessas massas resultaria num confronto entre a população - inclusive, infelizmente tivemos casos trágicos em resultado desses confrontos. Tive a ideia de construir uma máquina que teria como intenção reproduzir a tensão gerada por esse quase choque de forças opostas. Nela, criei dois pêndulos, esquerdo e direito, que se movimentam em sentidos opostos e cujas extremidades possuem dois fios elétricos desencapados. Estes fios estão ligados diretamente à energia da rede elétrica. Caso os pêndulos se encostassem, isto geraria um curto-circuito, desarmando o disjuntor e causando um blackout no espaço expositivo. Esse encontro entre essas forças opostas não era algo desejado, mas era algo que podia ocorrer.

Gosto quando as obras possuem camadas de assuntos que não são tão explícitos. Isso gera múltiplas leituras por parte do público. Vai depender da sensibilidade de cada um. weaken unity); and that a possible meeting of these masses would result in a confrontation between the population - and we unfortunately had tragic cases of these confrontations. I had the idea of building a machine that was intended to reproduce the tension generated by this almost clash of opposing forces. I created two pendulums, left and right, that move in opposite directions and at their ends there are two bare electrical wires. These wires are directly connected to the electric power source of the place. If the pendulums touch each other, this would generate a short circuit, tripping the circuit breaker, and causing a blackout in the exhibition space. This meeting between these opposing forces was not something desired but something possible to happen.

I like it when the works have layers of subjects that are not so explicit. This generates multiple readings by the visitors. It will depend on the sensitivity of each one. 


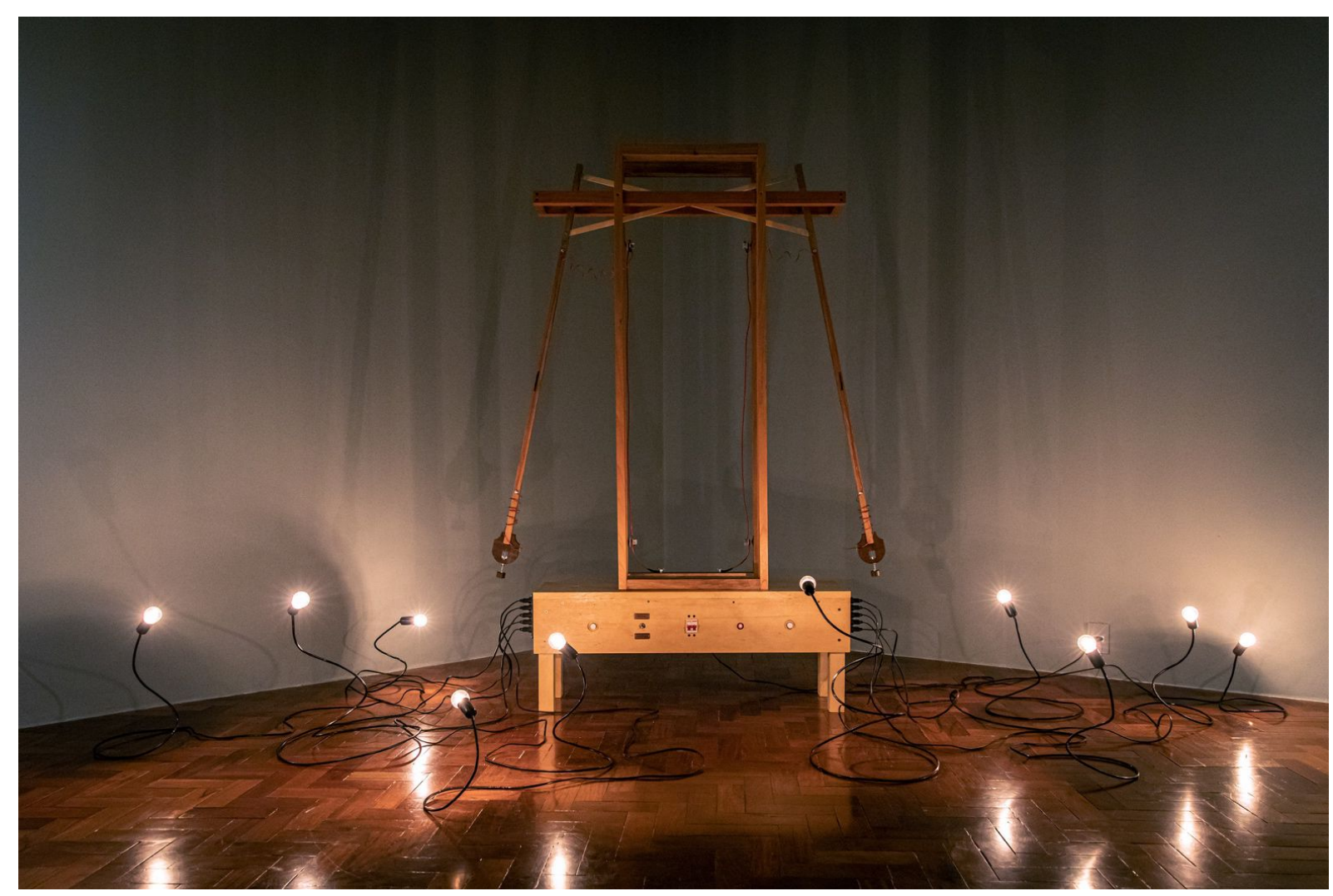

Fonte: Portfolio do artista.

Source: Artist's portfolio.

Ainda em relação ao contexto de invenção e de integração de materiais e linguagens que se destacam em sua produção artística, tal junção nos transmite a percepção de que a experimentação é um aspecto relevante para odesenvolvimento de seu processo criativo. Nesse sentido, como você vê o papel da pesquisa artística para o desenvolvimento de sua poética? Você poderia ilustrar descrevendo o processo de criação de alguma de suas obras sonoras?
Still regarding the context of invention and integration of materials and languages that stand out in your artistic works, such a combination conveys the perception that experimentation is a relevant aspect for the development of your creative process. In this sense, how do you see the role of artistic research in the development of your poetics? Could you illustrate it by describing the creative process of one among your sound works? 
A experimentação e a procura constante de aprender assuntos novos para a criação de minhas obras é o meu fio condutor, minha motivação.

Por exemplo, na criação da minha obra Speaker, minha ideia era criar um autômato, um cantor de jazz aleatório. Para isso, eu gravei minha própria voz cantando melodias improvisadas na técnica vocal do scat singing. Num programa de áudio, fiz a análise do espectro de frequências desta gravação, verifiquei o número de sílabas e palavras nas frases musicais, medi o tempo de intervalo entre as notas e a duração delas. Feita esta análise, criei uma tabela, onde adicionei todos esses dados como variáveis. Por exemplo, em relação ao espectro, obtive as frequências mais graves e mais agudas, bem como a média das frequências. Fiz o mesmo com todas as outras variáveis, inclusive adicionando o silêncio como uma variável. Com essa tabela, criei um programa que seria constantemente executado pelo microcontrolador Arduino. Neste programa, adicionei variáveis randômicas para cada um dos elementos, frequência, duração das notas, intervalo entre notas, tempo de silêncio, número de sílabas e palavras por frase. Também criei uma variável que determinava em qual alto-falante seria reproduzida a nota e qual a duração do tempo de ativação. Normalmente a obra fica em standby até que alguém interaja com ela ao pressionar um botão localizado na cabeça da escultura. Quando ativada, a obra toca durante um período de tempo de 3 a 7 minutos. O resultado sonoro, apesar de estranho, se aproximou muito das melodias que eu criei no improviso.
Experimentation and a constant search to learn new subjects for the creation of my works is my guiding thread - it is my motivation.

For example, in the creation of my work Speaker. In this work, my idea was to create a random jazz singer automaton. For this I recorded my own voice singing improvised melodies in the vocal technique of scat singing. In an audio editor program, I analyzed the frequency spectrum of this recording, verified the number of syllables and words in the musical phrases, measured the time interval between notes and the duration of these notes. After this analysis, I created a table, where I added all these data as variables. For example, in relation to the spectrum, I got the lowest and highest frequencies, as well as the average of the frequencies. I did the same with all other variables, including the addition of silence as a variable. With this table, I created a program that runs the Arduino microcontroller. In this program, I added random variables for each of the elements, frequency, note duration, interval between notes, silence time, number of syllables and words per sentence. I also created a variable that determined which speaker would play the note and how long the activation time would last. Usually, the work is on standby until someone interacts by pressing a button that the sculpture has on its head. When activated, the work plays for a time length of 3 to 7 minutes. The sound result, although strange, was very close to the melodies I created when improvising. 
Além dessa experimentação no campo da eletrônica digital, também teve a experimentação na construção da própria escultura. Eu tinha por objetivo e desafio criar uma estrutura inteiramente feita com tubos e conexôes usadas em redes de esgoto, a qual receberia a eletrônica embutida. $\mathrm{Na}$ loja de materiais de construção, fui até as prateleiras que continham as peças que eu iria utilizar e fiquei experimentando vários tipos de conexôes entre as peças, criando os pés, bocas, cabeças e tentáculos da escultura. No corredor da loja, depois de algumas horas experimentando (inclusive dispensando a ajuda de alguns vendedores que vieram ver se estava tudo bem), eu estava com a escultura pronta. Então coloquei tudo no carrinho e levei para o caixa.

Algumas de suas obras sonoras se abrem à descoberta de potencialidades expressivas conforme essas obras se desvelam sonoramente $\mathrm{e}$ cineticamente para o público que as vivenciam. Ao pensarmos que tal experiência com sons e movimentos ocorre no tempo, uma característica comum à experiência musical, surge uma grande dúvida: como você aborda o conceito de tempo em suas obras?

Para mim o tempo está ligado ao acaso, e juntos [sons e movimentos] cumprem a mesma função. A fruição acontece no tempo e por conta do acaso. Essa experiência é única para cada pessoa que a vivencia. De fato, é algo que se aproxima da experiência
In addition to this experimentation in the field of digital electronics, there was also experimentation in the construction of the sculpture itself. My goal and challenge was to create a structure entirely made with pipes and connections used in sewer systems, which would receive the built-in electronics. At the building materials store, I went to the shelves that kept the materials I was going to use, and experimented with various types of connections between the pieces, creating the sculpture's feet, mouths, heads, and tentacles. In the store's aisle, after a few hours of experimenting (including dispensing with the help of some sellers who came to see if everything was ok) I had the sculpture ready. Thus I put everything in the cart and took it to the cashier.

Some of your sound works open up the discovery of their expressive potential as they unveil themselves soundly and kinetically for the exhibition visitors that experience them. When we think that such experience with sounds and movements occurs in time, a characteristic akin to musical experience, a great question comes out: how do you approach the concept of time in your works?

For me time is linked to chance and together [sounds and movements] fulfill the same function. The fruition happens in time, and by chance. This experience is unique for each person who experiences it. In fact, it's something that 
musical, e mais ainda da música de improviso. Indo além, na minha obra $4,33 x$, temos também o pêndulo como uma referência espacial, o seu comprimento de 4,33 x metros, fazendo referência aos 4,33 minutos de silêncio [na obra] de John Cage. Porém, por uma questão física, esse mesmo comprimento é o que define o tempo de duração da oscilação do movimento do pêndulo, tempo convertido em espaço e convertido em tempo novamente. comes close to the musical experience, even more so to improvisational music. Going further, in my work $4,33 x$, we also have the pendulum as a spatial reference, its length of $4.33 \mathrm{x}$ meters referring to the 4,33 minutes of silence [in the work] by John Cage. However, for physical reasons, this same length is what defines the duration of the oscillation of the pendulum's movement - time converted to space and converted to time again.

FIGURA 10 - Teclado Sísmico?.

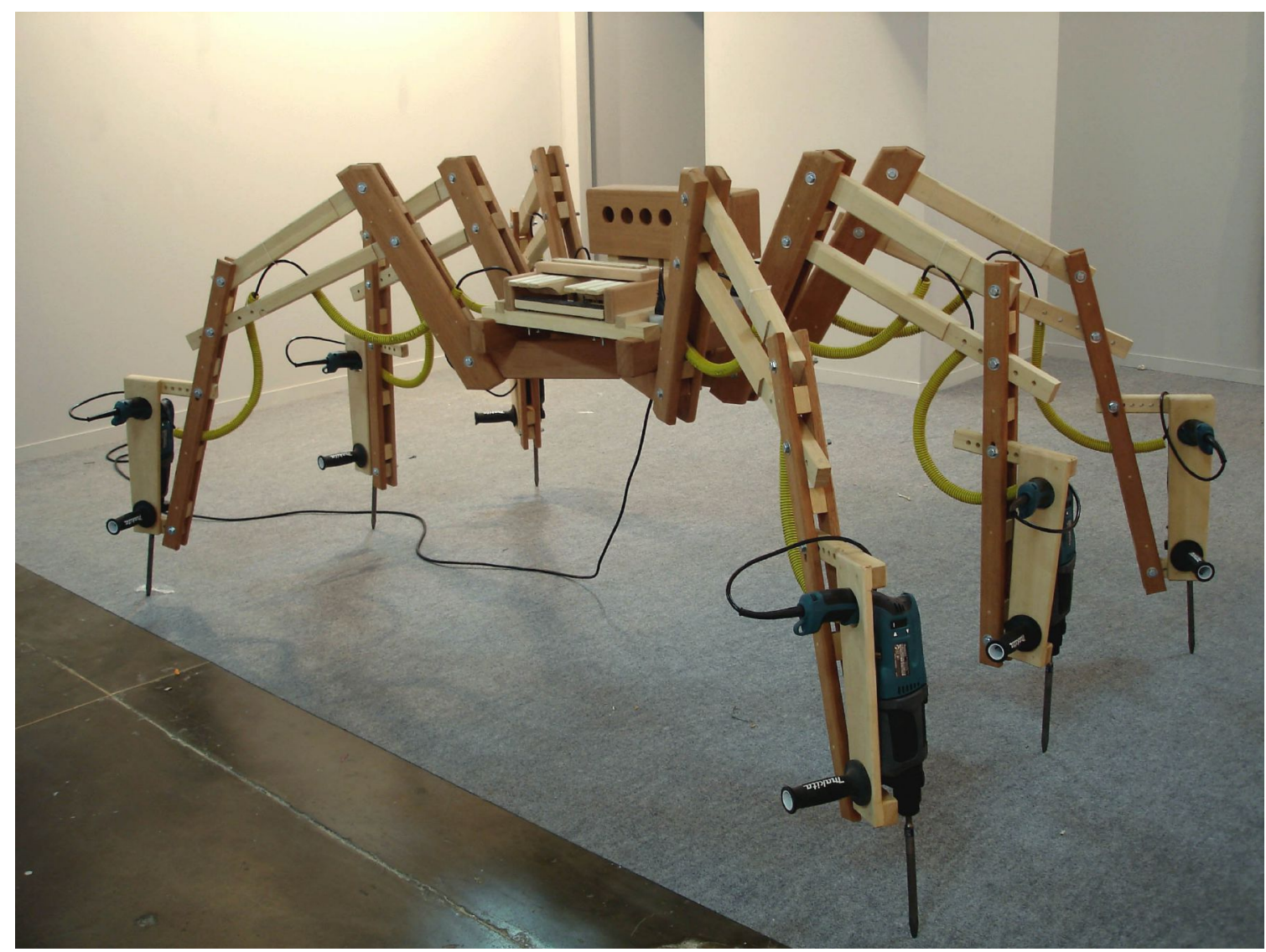

Fonte: Portfolio do artista.

Source: Artist's portfolio.

\footnotetext{
${ }^{9}$ Disponível em / available at: https://youtu.be/S5S1xlSHh2M. Acesso: 22 ago. 2021 / Accessed: Aug. $22,2021$.
} 


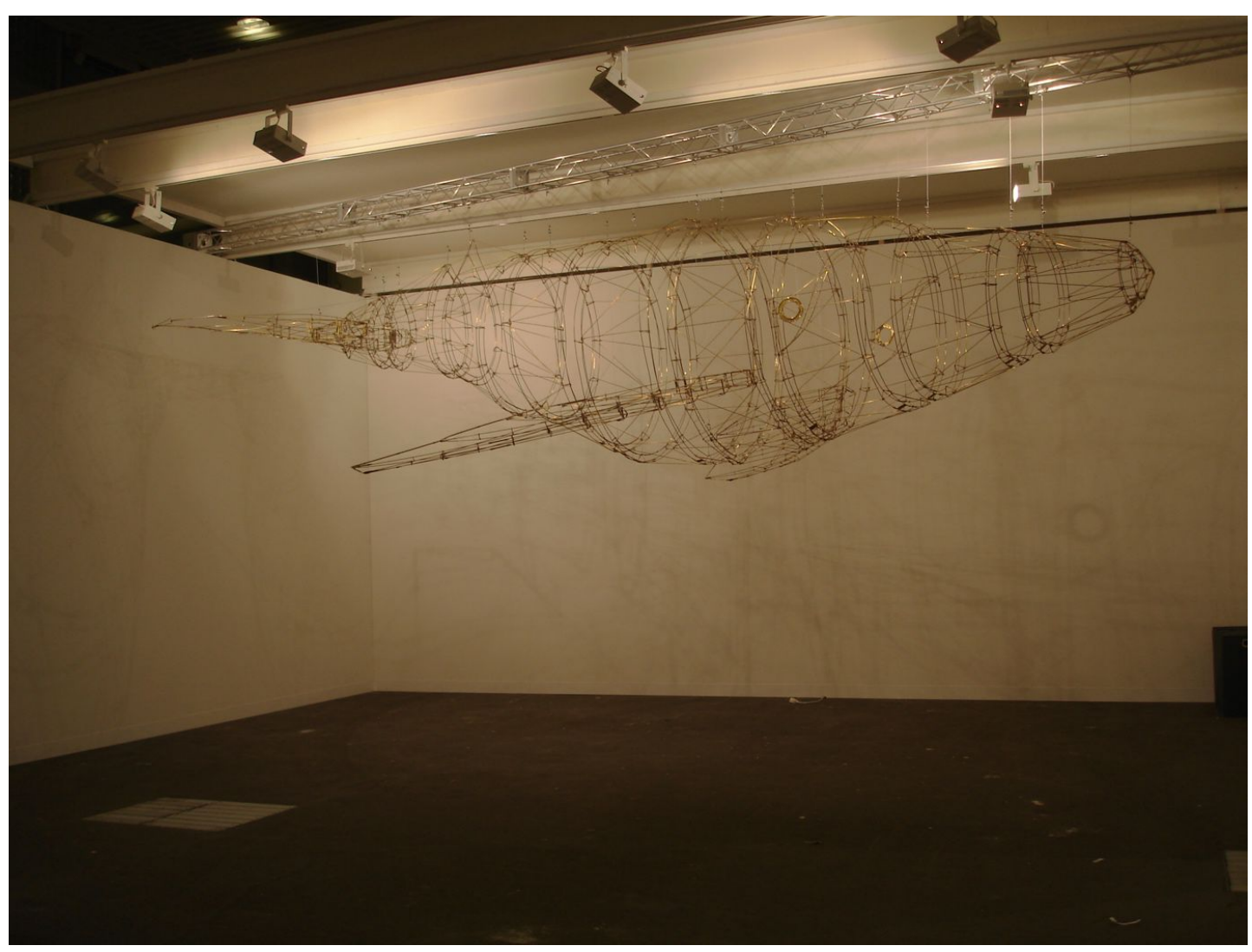

Fonte: Portfolio do artista.

Source: Artist's portfolio.

Uma das grandes dificuldades de se fazer arte com sons se deve ao planejamento acústico do espaço expositivo, já que muitas vezes as características arquitetônicas desses espaços não foram planejadas para receber obras sonoras e acabam gerando interferências ou criando relações entre as obras. No caso de suas exposições, especialmente as individuais, como ocorreu o planejamento de ocupação do espaço expositivo com essas obras que produzem sons, cuja percepção não se limita apenas ao escopo visual do visitante?
One of the great difficulties in making art with sounds is due to the acoustic planning of the exhibition space, since many times the architectural characteristics of these spaces were not designed to receive sound works and end up generating interference or creating relationships between the works. In the case of your exhibitions, especially the individual ones, how did you plan the occupation of the exhibition space with these works that produce sounds, whose perception is not limited to the visitor's visual scope? 
Desde a criação das minhas primeiras obras, essa foi uma preocupação, principalmente em relação à interferência do som das minhas obras em outras no caso de exposições coletivas. Em outros momentos, a intenção era de fato interferir, pois fazia sentido na poética da obra, como em Lugares Sonoros, de 2005. Neste trabalho, construí uma interface que possibilitava ao público percutir as estruturas metálicas do prédio do Centro Cultural São Paulo através de um teclado que acionava martelos percussivos fixados na edificação. Nos casos em que a intenção não era interferir em outras obras, adotei, na maior parte das vezes, duas soluções: mantê-las em silêncio ou deixar que a presença e/ou acionamento do público as ativassem, produzindo som. Logo, na maior parte do tempo, essas obras são silenciosas. Então, em vez de pensar no planejamento do espaço, pensei no planejamento do tempo. A primeira obra na qual usei este recurso foi a obra Lusco Fusco, também de 2005. Essa obra toca um carrilhão duas vezes ao dia. Ela é acionada pela intensidade da luz na aurora e no crepúsculo. No resto do dia, ela permanece em silêncio. Mais recentemente, em 2019, fiz uma grande exposição individual na Caixa Cultural da Sé, em São Paulo. A exposição foi denominada Invenções Hibridas. Nesta exposição, o espaço era todo aberto sem paredes. As obras ficavam espalhadas pelo espaço, algumas, em silêncio, aguardando a interação do público, e outras produzindo som constantemente. Nesse caso, o que teoricamente seria um problema, para mim acabou se tornando
Since the creation of my first works, this has been a concern mainly as to the interference of the sound of my works upon others, in the case of collective exhibitions. At times, the intention was actually to interfere to make sense out of the work's poetics, as in Lugares Sonoros, from 2005. In this work I built an interface that allowed the public to knock the metallic structures of the São Paulo Cultural Center through a keyboard that activated percussion hammers fixed in the building. If the intention was not to interfere, I adopted two solutions in the great majority of the works: keeping them silent or letting the public's presence and/or activation to start producing sound. Therefore, most of the time, these works are silent. So, instead of thinking about space planning, I thought about time planning. The first work that I used this resource was Lusco Fusco, also from 2005. It is a work that plays a carillon twice a day. It is triggered by the light intensity of dawn and dusk. For the rest of the day, it remains silent.

More recently, in 2019, I had a large solo exhibition at Caixa Cultural da Sé in São Paulo. The exhibition was called Invençôes Hibridas. In this exhibition, the space was completely open without walls. The works were scattered throughout the space. Some in silence awaiting the visitors' interaction, others constantly producing sound. In this case, what theoretically would be a problem, ended up being a quality of the exhibition. It seemed like if we were entering 
uma qualidade da exposição. Parecia que o público estava entrando num ambiente de uma floresta, e ao se aproximar de uma obra, se ouvia mais o som daquela do que das outras. Nossa percepção sonora tem essa capacidade de filtrar os sons que queremos ouvir sem muita dificuldade. Mas isso também foi possível porque o nível de amplitude sonora de todas as obras era bem parecido. Tive a oportunidade de participar de uma exposição coletiva na qual não estive presente na montagem. Quando fui visitar a exposição, me dei conta de que o planejamento das obras havia sido mal feito, prejudicando o meu trabalho. Eu estava expondo uma obra sonora e acústica (não havia amplificação), e a menos de 10 metros da minha obra havia uma obra de outro artista que possuía um ventilador daqueles de inflar bonecos usados em propaganda. A amplitude do som era extremamente alta e constante, o que prejudicou a fruição da minha obra. Enfim, faltou planejamento na disposição das obras.

$\mathrm{Na}$ direção contrária, tive a alegria de participar de outra exposição que era específica de arte sonora e cujo espaço foi inteiramente planejado, desenhado e construído, com isolamento acústico entre as obras. Era incrível. Era uma exposição de arte sonora na qual você conseguia ouvir com nitidez cada uma das obras sem a interferência das demais. Existem possibilidades, intenções e soluções diversas. O problema é quando falta planejamento mesmo. in a forest environment, and when approaching a work, its sound would be heard more than the others. Our sound perception has this ability to filter the sounds we want to hear without too much difficulty. However, this was also possible because the sound amplitude level of all the works was very similar. I had the opportunity to participate in a collective exhibition in which I was not present in the assembly. When I went to visit the exhibition, I realized that the planning of the works had been poorly done and so, my work was harmed. I was exhibiting a sound and acoustic work (there was no amplification) and less than 10 meters from my work there was a work by another artist who had a fan of those tube men used in advertising. The amplitude of the sound was extremely loud and constant, which hindered the enjoyment of my work. Finally, there was a lack of planning in the disposition of the works.

In the opposite path, I had the joy of participating in another exhibition, which was specific to sound art, whose space was entirely planned, designed and built, with sound insulation between the works. It was amazing, it was an exhibition of sound art where you could clearly hear each of the works without any interference by others.

There are different possibilities, intentions and solutions. The problem is when it just lacks planning. 


\section{SOBRE OS AUTORES / ABOUT THE AUTHORS}

Roseane Yampolschi: Composer and interdisciplinary artist. Music Professor at the Federal University of Paraná. Graduated in Music Composition from the Federal University of Rio de Janeiro, earned a MA degree in Music from Eastern Illinois University and a DMA degree from the University of Illinois at Urbana-Champaign (USA). Reveived many prizes and distinctions for her works in Brazil and abroad, such as the Biennial Festival of Brazilian Contemporary Music (Rio de Janeiro), the International Fund for the Promotion of Culture by UNESCO, and the ISCM Festival World Music Days (Romania and Norway). As a researcher, her main interests today are focused in the areas of gestural embodiment in creative processes, interdisciplinarity and contemporary musical aesthetics / poetics. ORCID: https://orcid.org/0000-0002-4615-8116. E- mail: ryampolschi@gmail.com

Clayton Rosa Mamedes: Professor in the Music Graduate Program at Federal University of Paraná (UFPR), professor at State University of Paraná (UNESPAR - EMBAP) and coordinator of the Laboratory of Music, Sonology and Audio (LaMuSA-UNESPAR). Doctor in music from the State University of Campinas (Unicamp), holding master and bachelor degrees in music composition also from Unicamp. Develops researches in the areas of multimedia installations, interaction, sound design, spectral music and electroacoustic music. ORCID: https://orcid.org/0000-0003-4355-8111. E-mail: claytonmamedes@gmail.com

Paulo Nenflidio is an artist who works at the intersection of art, science and technology. Graduated in Fine Arts from the School of Communication and Arts of the São Paulo University and in Electronics from Technical State School Lauro Gomes. His works include sculptures, installations, objects, instruments and drawings. Sound, electronics, movement, construction, invention, randomness, physics, control, automation and workaround are present in his work. His works look like animals, musical instruments or science fiction machines. In 2003 he participated in the Bolsa Pampulha artistic residency in Belo Horizonte, having performed the work Música dos Ventos. In 2005, he received the Sérgio Motta Art and Technology Award for his work. In 2009 he held an artist residency at the ASU Art Museum in Arizona, having produced an individual exhibition during the residency period. He participated in the 7 th Mercosul Visual Arts Biennial and in the Paralela 2010 exhibition. In 2011 he received the CNI SESI Marcantonio Vilaça Visual Arts Award and in 2013 the Funarte Marcantonio Vilaça Award. In 2017 he participated in the International Biennial of Contemporary Art in South America. ORCID: https://orcid.org/0000-0002-6415-8849. E-mail: paulonenflidio@yahoo.com.br 